\title{
DETERMINATION OF OPTIMUM CONDITIONS FOR THIN-LAYER DRYING OF LEMON BALM LEAVES (MELISSA OFFICINALIS L.)
}

\author{
Baher M. A. Amer*
}

\begin{abstract}
$\underline{\text { ABSTRACT }}$
Drying kinetics of Melissa officinalis were investigated in a laboratory scale hot air dryer at an air velocity of $0.5,0.75$ and $1.00 \mathrm{~m} / \mathrm{s}$ and temperature range of 30,40 and $50^{\circ} \mathrm{C}$ to find out the optimum drying conditions in terms of drying rate.

Drying rate increased significantly with the increase in air temperature. Drying rate increased with the increase of air velocity up to $1.0 \mathrm{~m} / \mathrm{s}$. Above this air velocity, drying rate became independent of air velocity. The optimum drying air conditions was the temperature of $50^{\circ} \mathrm{C}$ and air velocity of $1.0 \mathrm{~m} / \mathrm{s}$, when drying time was considered. The experimental data were fitted to determine the drying constant " $k$ " for drying lemon balm in thin layer. Hence, optimum lemon balm in color may be dried at an air temperature of $40^{\circ} \mathrm{C}$ and air velocity of from 0.75 to $1.0 \mathrm{~m} / \mathrm{s}$ and this is the maximum air temperature may be recommended to describe the thin layer drying of lemon balm. The effective moisture diffusivity was determined of lemon balm during drying. The effective moisture diffusivity of Melisa increased linearly from $9.2 \times 10^{-10}$ to $2.16 \times 10^{-9} \mathrm{~m}^{2} / \mathrm{s}$ as drying air temperature increased from 30 to $50^{\circ} \mathrm{C}$. The activated energy of Melissa officinalis was calculated and found to be $24.62 \mathrm{~kJ} / \mathrm{mol}$.
\end{abstract}

\section{INTRODUCTION}

T $\mathrm{n}$ Egypt, the medicinal plants in the recent years have an important export value and they are considered as a natural alternative to chemical drugs because of their medical side effect, (Shokr et al., 2011). Therefore, some experiments were conducted for thin-layer of herbal plants as (Arafa, 2007, Abdel Ghaffar et al., 2011).

\footnotetext{
*Lec., Agric. Eng.; Fac. of Agric.; Cairo University-Egypt
} 
Lemon balm (Melissa officinalis L.) is a perennial herb of the family Lamiaceae, cultivated for the characteristic lemon-scented leaves, Fig. 1. It is implemented for several purposes in the food, pharmaceutical and cosmetic industries due to its flavoring, medicinal and therapeutic properties.

It makes both delicious beverage and medicinal teas. It is also nice to add to black tea. Fresh leaves can be chopped and added to green salads, fruit salads, marinated vegetables, poultry stuffing and fish marinated and sauces. Medicinally Lemon Balm is used in tea for fever to help digestion and for tension headache. The essential oil is used in aromatherapy for depression, melancholy and nervous tension. Externally in salve, it has been effective in relieving symptoms of herbs simplex, sores and painful swellings. A compress is good for gout. In addition, it is used in cosmetic to make a good skin cleanser. Rub down the kitchen tables with the herbs to keep bugs from the product and throw some in the campfire to keep bugs away. Beekeepers have rubbed it on the inside of the hives to encourage a new swarm to stay, (Halsey, 1985).

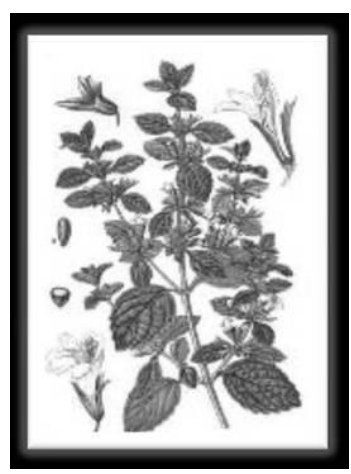

Fig. 1. Fresh plant of Lemon Balm

Drying of Melissa officinalis is carried out by mechanical drying. Therefore, it is important to know its drying characteristics. The drying rate of Melissa officinalis is closely associated with the drying air temperature, relative humidity and air velocity.

It is essential to dry Melissa officinalis in a suitable environment to produce a good quality dried products. The efficiency of the drying system can be improved by the analysis of the drying process. Analysis of 
the drying system can be greatly expedited by using computer simulation. A generalized thin layer herbs drying equation is therefore, needed for this purpose. The equation should be suitable for use at any temperature, relative humidity and air velocity of the drying air used in lemon balm drying.

Understanding of the characteristics of herbs in terms of drying kinetics is essential for designing, modeling and optimization of drying systems. Since Buser et al,. (1999) reported that the pigment content degrade at higher drying temperature when they studied the effect of drying temperature and airflow rates on the detachment marigold petals.

Little information is available in the literature on drying characteristics of lemon balm in thin-layer at different air temperatures, air relative humidities and air velocities. However, information about the influence of the drying process on the color of lemon balm is still limited in literature. Therefore this work has been undertaken to study drying kinetics of Melissa officinalis in thin-layer to optimize the drying process in terms of some drying parameters such as air temperature, air relative humidity and air velocity. In addition, to evaluate the effect of temperature of drying air on the color of M. officinalis leaves in order to establish a reference for optimum color quality among different drying conditions.

\section{MATERIALS AND METHODS}

\section{A. Plant material}

Fresh plants of lemon balm, cultivar Citronella were collected from an organic farm at Magstadt (Germany) in June and July before flowering. Prior to drying experiments, the leaves were manually separated from the stalks.

\section{B. Laboratory Dryer}

The experiments of drying of a thin layer drying of Lemon Balm (Melissa officinalis $L$.) at various air temperature and air velocity were conducted in a laboratory scale dryer as shown in Figures. 2 and $\mathbf{3}$ at the LeibnizInstitut für Agrartechnik-Bornim, Potsdam Germany during June to September 2009. The dryer mainly consisted of a blower, heating unit, plenum chamber, drying chamber, sample container, a digital balance and 
data logger. A thermostat was used to control the temperature in the drying chamber. A controller was used to adjust the air velocity in the drying chamber. A series of sensors was inserted in the drying chamber to measure the air temperature and relative humidity. The sensors were connected with a PC via data logger for recording instantaneous data.

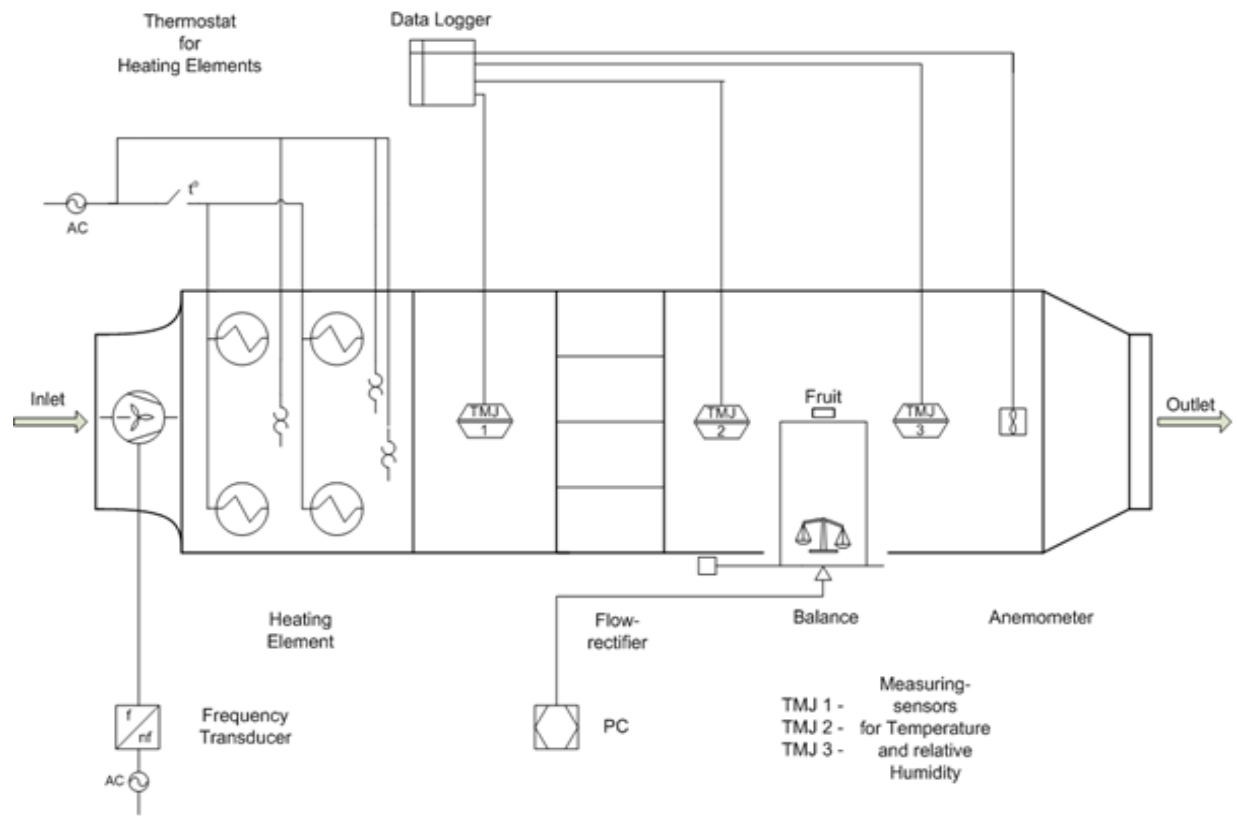

Fig. 2. Schematic view of a laboratory scale thin-layer dryer

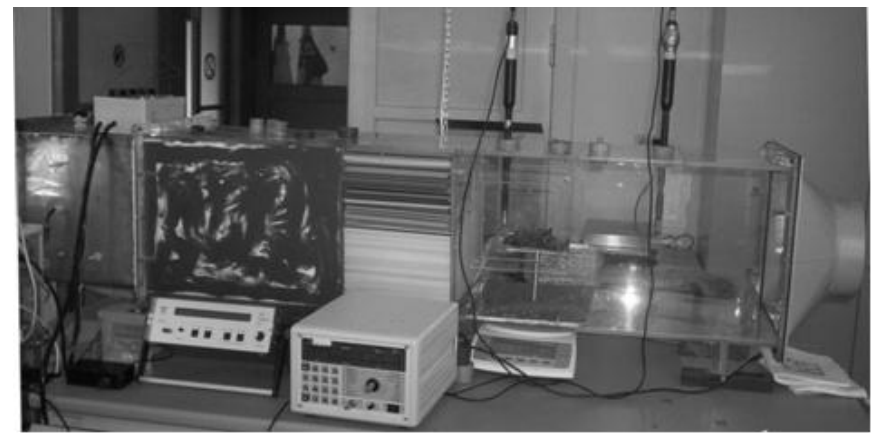

Fig. 3. Photographic view of a laboratory scale thin-layer dryer

The initial moisture content of fresh Lemon Balm (Melissa officinalis L.) was determined by atmospheric air oven method at $105 \pm 2{ }^{\circ} \mathrm{C}$ for 24 
hours, (AOAC 1975). The moisture content (dry basis) was calculated according to the following definitions

$$
\mathrm{M}_{\mathrm{d}}=\left[\frac{\mathrm{w}_{\mathrm{w}}-\mathrm{w}_{\mathrm{d}}}{\mathrm{W}_{\mathrm{d}}}\right]
$$

Where

$\mathrm{M}_{\mathrm{d}}$ moisture content of plants, (dry basis), \%

$\mathrm{W}_{\mathrm{w}}$ mass of wet plants, $(\mathrm{g}) \quad \mathrm{W}_{\mathrm{d}}$ mass of dry matter, $(\mathrm{g})$

The drying rate $(D R)$ and moisture ratio $(M R)$ of lemon balm leaves were calculated using the following definitions:

$$
\begin{aligned}
& D R=\frac{M_{t+d t}-M_{t}}{d t} \\
& M R=\frac{M_{t}-M_{e}}{M_{o}-M_{e}}=\exp (-\mathrm{k} \mathrm{t})
\end{aligned}
$$

where the drying rate, $D R$, is expressed as the amount of the evaporated moisture over time ( $\left.\mathrm{g}_{\text {water }} / \mathrm{g}_{\text {dry matter }} . \mathrm{sec}\right) . M R$ is the moisture ratio, $\mathrm{M}_{\mathrm{t}}$ is the moisture content at a specific time ( $g_{\text {water }} / \mathrm{g}_{\text {dry base }}$ ), $\mathrm{M}_{\mathrm{o}}$ is the initial moisture content ( $\left.g_{\text {water }} / \mathrm{g}_{\text {dry base }}\right), \mathrm{M}_{\mathrm{e}}$ is the equilibrium moisture content ( $\left.\mathrm{g}_{\text {water }} / \mathrm{g}_{\text {dry base }}\right), \mathrm{M}_{\mathrm{t}+\mathrm{dt}}$ is the moisture content at $\mathrm{t}+\mathrm{dt}\left(\mathrm{g}_{\text {water }} / \mathrm{g}_{\text {dry base }}\right), \mathrm{k}$ is the drying constant $\left(\mathrm{min}^{-1}\right)$ and $\mathrm{t}$ is drying time $(\mathrm{min})$. The equilibrium moisture content $\left(\mathrm{M}_{\mathrm{e}}\right)$ was assumed to be until the drying process almost constant when the moisture content of plants fell down to $0.1 \pm 0.05$ on dry basis, (Alibas, 2007). The drying data, reported as moisture ratio MR versus drying time, were fitted to determine the drying constant " $\mathrm{k}$ ". This commonly used thin layer equation was used to fit the experimental data by the direct least square method using SPSS 16.0 software. This constant could be determined also using Excel spreadsheet by plotting "In MR" vs. ' $\mathrm{t}$ " results in a slopping down straight line whose slope is " $\mathrm{k}$ " as follows, (Mosallam et al., 2011)

$$
\mathrm{Ln} M R=-\mathrm{k} \mathrm{t}
$$




\section{Thin Layer Drying Experiment}

Thin layer drying experiments were conducted at 30,40 and $50^{\circ} \mathrm{C}$ drying air temperatures and air velocity of $0.50,0.75$ and $1.00 \mathrm{~m} / \mathrm{s}$. Experiments were also conducted of lemon balm optimum conditions. Before starting the experiment all equipment was checked very carefully and was run for the required drying condition until the system had become stable. For each experiment a single thin-layer with face upward was placed on the sample container in the drying chamber. Conditioned drying air flowed over and under the surfaces and the weights; temperatures and relative humidity were recorded at every ten minutes with a data logger. The datalogging interval was adjusted at 5 minutes. The air off period for data recording was set at 30 seconds. After 4 minutes 30 seconds, the blower was automatically off and the balance became stable and data was recorded in still air in 10 seconds. Thin layer experimental runs were conducted at 30,40 and $50^{\circ} \mathrm{C}$ temperatures. Three replicate experiments under identical drying conditions were conducted.

\section{Color measurement}

Leaf color was determined for the two surface of the leaves using a Minolta CR 300 colorimeter (Konica- Minolta, Osaka, Japan), calibrated with a white standard tile. The color brightness coordinate " $\mathrm{L}$ *" measures the whiteness value of a color and ranges from black at 0 to white at 100 . The chromaticity coordinate " $a$ *" measures red when positive and green when negative, and the chromaticity coordinate " $b$ *" measures yellow when positive and blue when negative. Color saturation " $\mathrm{C}$ *" or chroma indicates color saturation and is proportional to its intensity. It was calculated from the values "a*", "b*" and it was used to describe the color change as follows, (Soysal, 2004):

$$
\text { Chroma }=C^{*}=\sqrt{\left(a^{*}\right)^{2}+\left(b^{*}\right)^{2}}
$$

\section{F. Moisture Diffusivity and Activation Energy}

The diffusion equation for slab geometry was solved by assuming uniform initial moisture distribution, negligible external resistance, 
constant diffusivity, and negligible shrinkage (Crank, 1975 and Lee and Hsieh, 2008):

$$
M R=\frac{8}{\pi^{2}} \sum_{n=0}^{\infty} \frac{1}{(2 n+1)} \exp -\left(\frac{(2 n+1)^{2} \pi^{2} D_{e f f} t}{4 L^{2}}\right)
$$

Where $n$ is number of order $(0,1,2,3, \ldots), M R$ is a dimensionless moisture ratio, $D_{\text {eff }}$ is the effective moisture diffusivity $\left(\mathrm{m}^{2} \mathrm{~s}^{-1}\right), t$ is the time (s), and $L$ is the half-thickness of sample (m). This model assumes zero volume change, negligible external mass transfer resistance (infinite Biot number for mass transfer), and an isothermal process.

The diffusion equation developed for particles with slab geometry is applicable assuming that the diffusivity is constant and the equation is therefore simplified and linearized as follows:

$$
\ln M R=\ln \left(\frac{8}{\pi^{2}}\right)-\left(\frac{\pi^{2} D_{e f f} t}{4 L^{2}}\right)
$$

The Eqn. (3) for modified thickness was fitted to the experimental data of Melissa and the diffusivity can be determined minimizing sum of squares of the deviations between the predicted and experimental data.

The effective moisture diffusivity can be expressed by simple Arrhenius equation as a

$$
D_{\text {eff }}=D_{o} \exp \left(-\frac{E_{a}}{R T}\right)
$$

where

$D_{o}$ is a constant equivalent to the effective diffusivity at infinite high temperature $\left(\mathrm{m}^{2} \mathrm{~s}^{-1}\right), E_{a}$ is the activation energy $\left(\mathrm{kJ} \mathrm{kg}^{-1}\right), R$ is the gas constant $\left(\mathrm{kJ} \mathrm{kmol}^{-1} \cdot \mathrm{K}^{-1}\right)$, and $T$ is the temperature of air $(\mathrm{K})$.

From Eqn. (4), activation energy was calculated by non-linear regression analysis.

\section{RESULTS AND DISCUSSION}

\section{A. Effect of Air Temperature on the thin layer drying of lemon balm}

The effect of air temperature on thin layer drying of Lemon Balm (Melissa officinalis L.) is shown in Figure 4. Moisture loss increased with an increase in drying air temperature. Although, the difference between 
the drying time in the case of $50^{\circ} \mathrm{C}$ was not clear shorter than in the case of $40^{\circ} \mathrm{C}$ due to the initial of moisture content for Melissa was higher in the case of $50^{\circ} \mathrm{C}$ than in the case of $40^{\circ} \mathrm{C}$. Time required for drying of Lemon Balm (Melissa officinalis L.) sample at constant air velocity (1.0 $\mathrm{m} / \mathrm{s}$ ) and 30,40 and $50^{\circ} \mathrm{C}$ air temperature were about 902.01, 798.42 and 570.32 minutes respectively. There is a constant rate period of drying and drying took place also in the falling rate period.

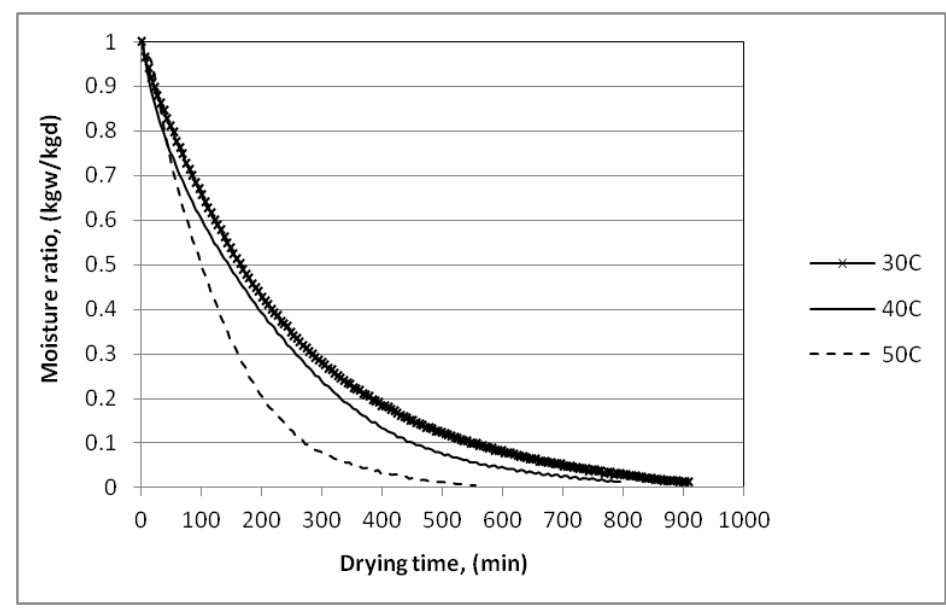

Fig. 4: Thin layer drying of Lemon Balm (Melissa officinalis $L$.) at different air temperatures $(\mathrm{v}=\mathbf{1 . 0 0} \mathrm{m} / \mathrm{s})$

The increase in air temperature to accelerate the drying process was limited in some cases due to the initial moisture content of Lemon Balm.

\section{B. Relation of air temperature and relative humidity with the drying constant of lemon balm}

The relation between the drying constant " $k$ " versus the air temperature "T" and air relative humidity "RH" for thin layer of drying lemon balm was shown in Fig. 5 and 6, respectively.

It was showed in the figure 5 that the drying constant was increased almost linearly by increasing the values of air temperature. However, it was showed in the figure 6 that the drying constant was decreased almost linearly by increasing the values of air relative humidity. 


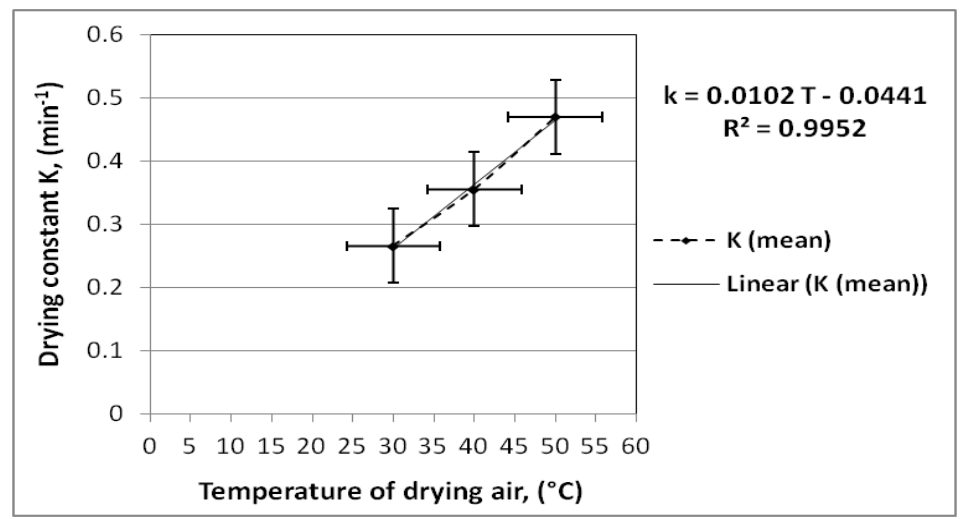

Fig. 5. Relation between the drying constant " $k$ " and air temperature " $T$ " for thin layer of drying lemon balm.

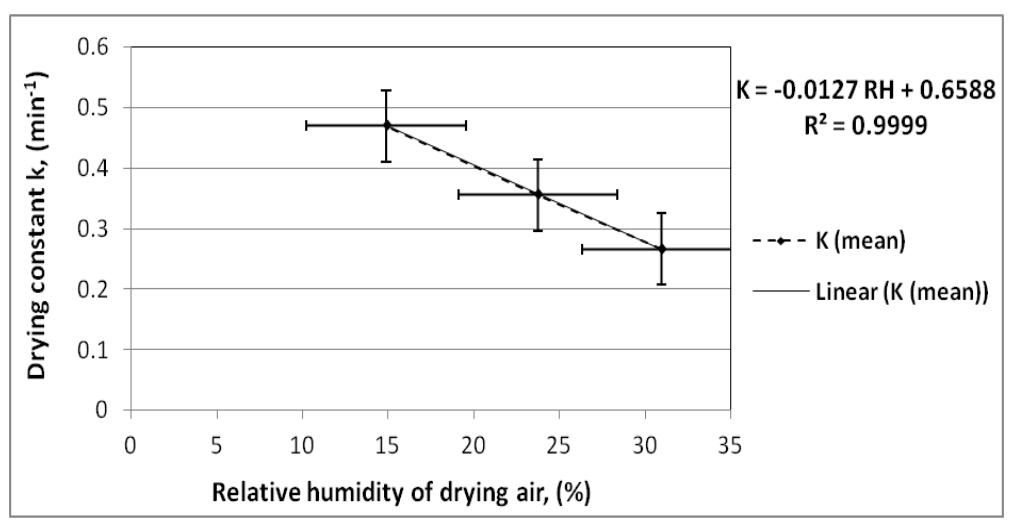

Fig. 6. Relation between the drying constant " $k$ " and drying air relative humidity "RH" for thin layer of drying lemon balm.

A multiple regression analysis by SPSS 16 was employed for determination the interaction effect of both drying air temperature and air relative humidity on the drying constant " $\mathrm{k}$ " for thin layer of drying lemon balm as the following equation:

$$
\mathrm{k}=1.342-0.010 \mathrm{~T}-0.025 \mathrm{RH} \quad \mathrm{R}^{2}=0.9054
$$

The analysis revealed that the drying constant " $\mathrm{k}$ " showed a highly dependent on both air temperature and relative humidity. These results are in agreement with Matouk et al., (2002). The previous equation could be shown in Fig. 7 to present the relation between the experimental drying 
constant " $k_{\exp }$ " and predicted drying constant " $k_{\text {pre" }}$ by the regression model for thin layer of drying lemon balm.

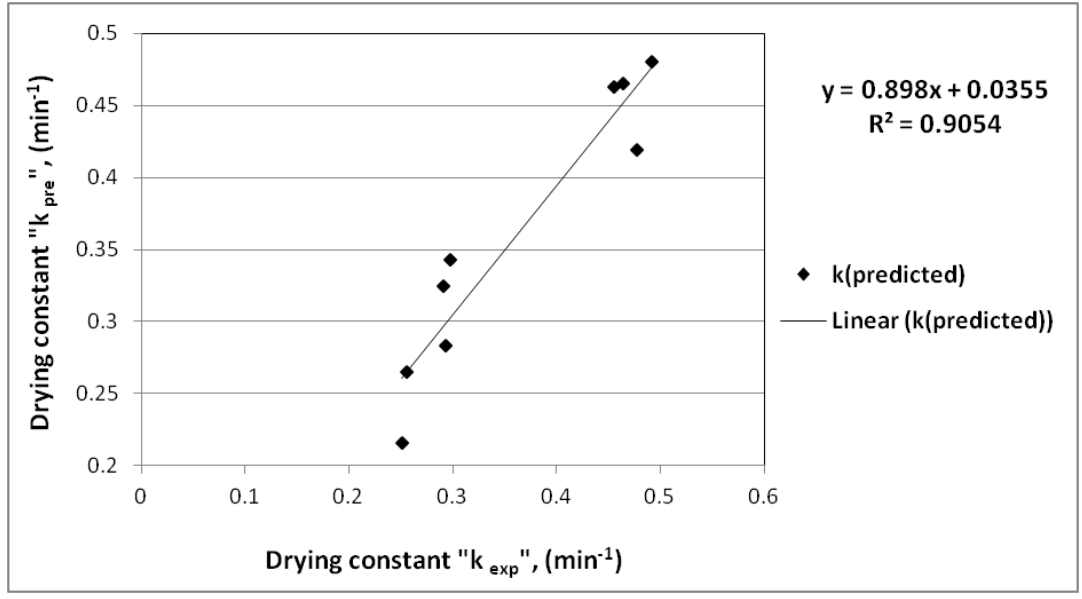

Fig. 7. Relation between the experimental drying constant " $k_{\exp }$ " and

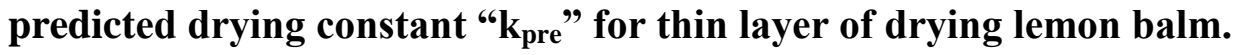

\section{Effect of air velocity on the thin layer drying of lemon balm}

The effect of air velocity on the thin layer drying of Lemon Balm (Melissa officinalis L.) is given in Figure 8. The moisture loss of it was faster at the higher air velocity and increased with air velocity, but the effect is not pronounced as the effect of the air temperature.

For an increase of air velocity from 0.5 to $0.75 \mathrm{~m} / \mathrm{s}$ and $1.00 \mathrm{~m} / \mathrm{s}$, the moisture loss of lemon balm increased; the drying rate of Melissa was almost constant. Time required for drying of lemon balm sample at constant air temperature $50^{\circ} \mathrm{C}$ and $0.50,0.75$ and $1.00 \mathrm{~m} / \mathrm{s}$ air velocity were about 570, 539 and 539 minutes respectively. The initial moisture content for lemon balm was a little bit higher in the experiment of 1.00 $\mathrm{m} / \mathrm{s}$ than its value in the experiment of $0.75 \mathrm{~m} / \mathrm{s}$ and this is the reason for the drying time for the two experiments is almost the same instead of to be shorter in the case of $1.00 \mathrm{~m} / \mathrm{s}$.

Hence, drying rate became independent of air velocities for the air velocity above $0.75 \mathrm{~m} / \mathrm{s}$. Air velocity above this value should be avoided to save energy. 


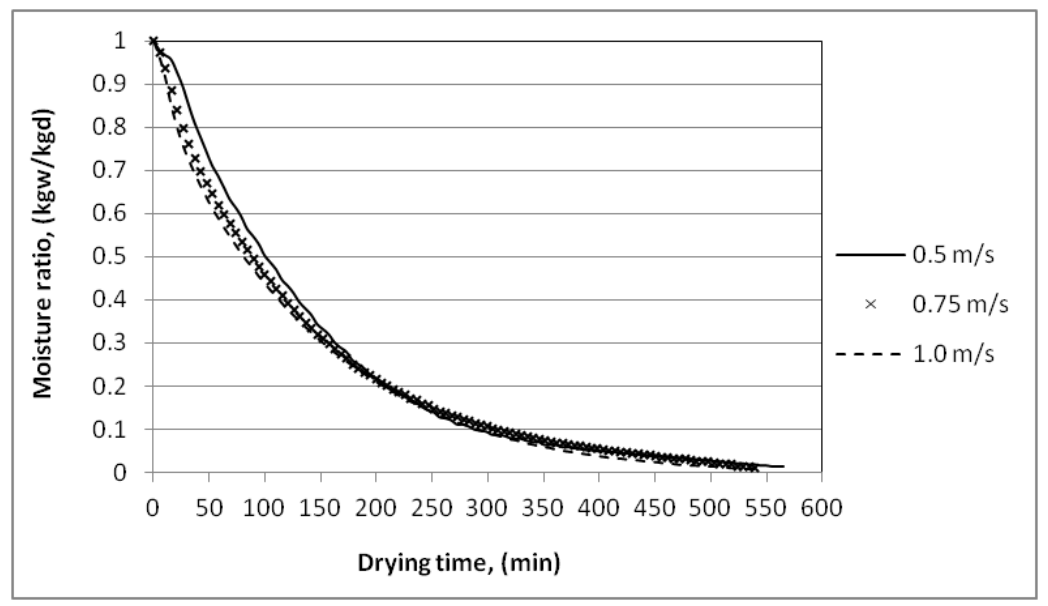

Fig. 8. Thin layer drying of Lemon Balm (Melissa officinalis $L$.) at different air velocity $\left(\mathrm{T}=50^{\circ} \mathrm{C}\right)$

Figures 9 and 10 show the drying rate versus drying time at temperatures of 30,40 and $50^{\circ} \mathrm{C}$ of drying air with constant air velocity of $1 \mathrm{~m} / \mathrm{s}$, and $0.5,0.75$ and $1.0 \mathrm{~m} / \mathrm{s}$ with constant air temperature $50^{\circ} \mathrm{C}$, respectively. It was shown that the constant drying rate was finished after a short period from the beginning of heating of the samples; afterwards, the product dries itself in the falling rate period.

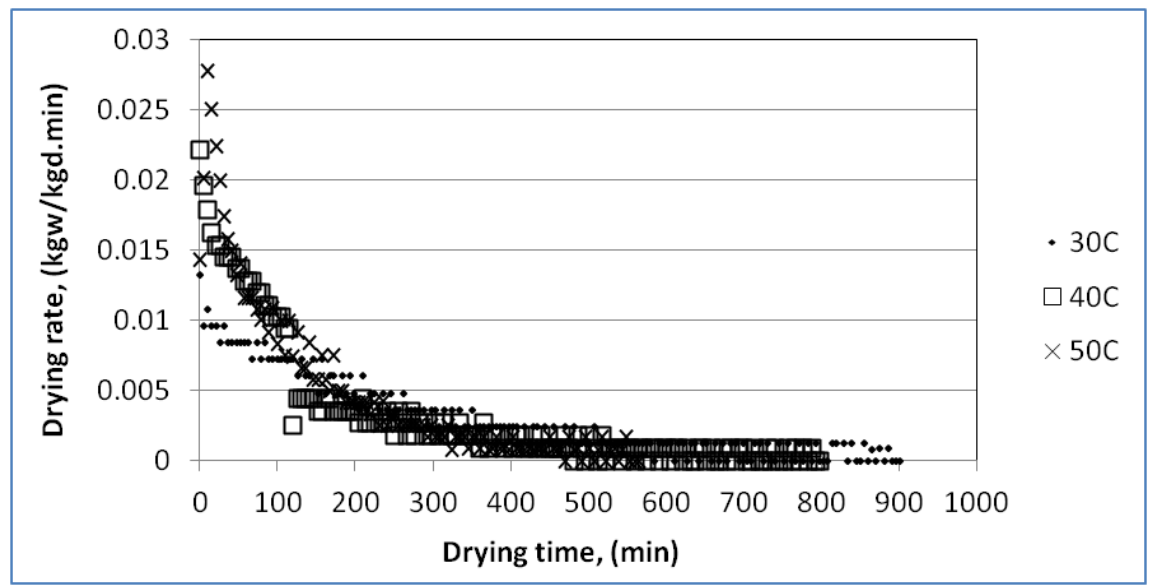

Fig. 9. The drying rate of lemon balm versus time at temperatures of 30,40 and $50^{\circ} \mathrm{C}$ of drying air with constant air velocity of $1 \mathrm{~m} / \mathrm{s}$ 
From Fig. 9, it was shown that the air temperature is a great factor on the drying rate for thin layer of lemon balm. Although, in Fig. 10 it was shown that the small effect for the air velocity on the drying rate for thin layer of lemon balm.

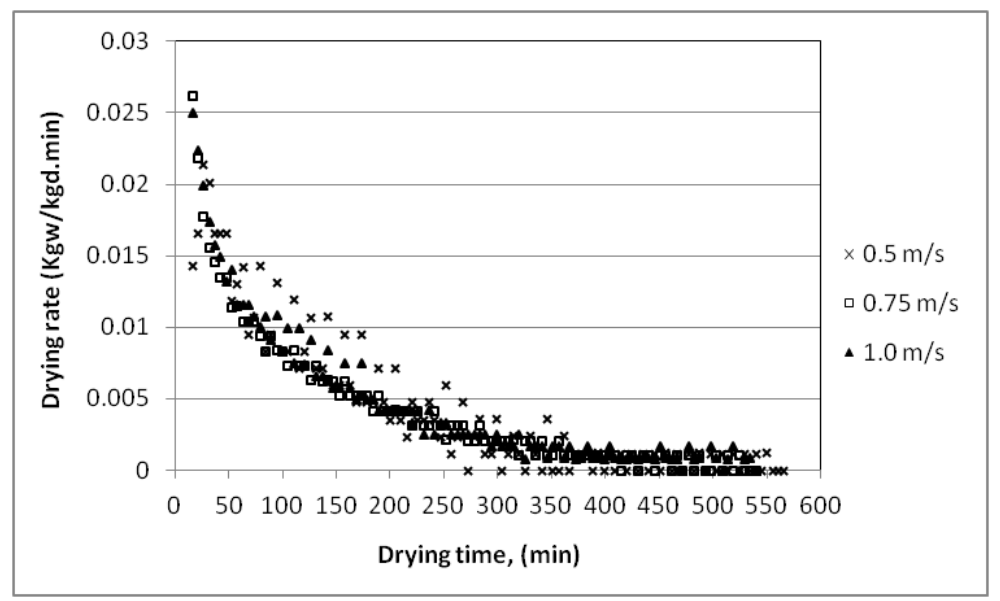

Fig. 10. The drying rate of lemon balm versus time at air velocity of $0.5,0.75$ and $1 \mathrm{~m} / \mathrm{s}$ with a constant drying air temperature of $50^{\circ} \mathrm{C}$

Since, the initial moisture contents of lemon balm leaves used in drying experiments were relatively constant (2.7 to $2.9 \mathrm{~g}_{\text {water }} / \mathrm{g}_{\mathrm{dry}}$ base), the difference in drying time requirements was considered to be mainly due to the difference in the drying rates which were given in Figs. 8 and 9. As can be seen from these figures, depending on the drying conditions, the main stage of drying rates for thin layer of lemon balm is the falling rate period.

\section{Evaluation of color parameters}

The individual color parameters of fresh lemon balm leaves were taken as a reference in order to evaluate the extent of color change. These values and the statistical results of the color measurements of lemon balm leaves dried at different conditions are presented in table 1. The statistical analysis implied that the color of fresh leaves was significantly different than that of dried leaves. 
The lightness " $\mathrm{L}^{*}$ " or redness represented by "a*" value might be considered as an objective indicator of the color quality of plants. This result was agreed with the results by Argyropoulos et al. (2009).

Table $1 . \mathrm{L}^{*}, \mathrm{a}^{*}, \mathrm{~b}^{*}$, and $\mathrm{C}^{*}$ color parameters of dried lemon balm leaves at different drying conditions

\begin{tabular}{ccccc}
\hline Color parameters & Fresh plants & \multicolumn{3}{c}{ Drying air temperature, ${ }^{\circ} \mathbf{C}$} \\
\hline & & 30 & 40 & 50 \\
\cline { 3 - 5 } & & & & \\
$\mathrm{L}^{*}$ & 45.34 & 46.57 & 44.40 & 39.70 \\
\hline $\mathrm{a}^{*}$ & -17.12 & -6.47 & -1.52 & 0.32 \\
\hline $\mathrm{b}^{*}$ & 24.52 & 12.98 & 11.13 & 8.02 \\
\hline $\mathrm{C}^{*}$ & 28.88 & 16.32 & 14.50 & 9.96 \\
\hline
\end{tabular}

Drying air temperature showed significant effect on the color of the leaves as expressed by " $L$ " values. The lightness of the dried leaves was maintained constant at $30^{\circ} \mathrm{C}$ and slightly decreased at $40^{\circ} \mathrm{C}$ as compared with the " $L^{*}$ " value of fresh leaves. Nevertheless, for an increase in air temperature over $50^{\circ} \mathrm{C}$ remarkable loss of lightness was detected. Similar observation was documented for saturation " $\mathrm{C} *$ ".

\section{E. Moisture Diffusivity and Activation Energy}

The effective moisture diffusivity was determined considering for herbs during drying and the shape of Lemon Balm (Melissa officinalis L.) was assumed as slab shape. The effective moisture diffusivity of Lemon Balm (Melissa officinalis L.) could be determined by Eqn. 3. It was increased linearly from $7.88 \times 10^{-10}$ to $8.00 \times 10^{-9} \mathrm{~m}^{2} / \mathrm{s}$ at drying air temperature $30^{\circ} \mathrm{C}$ as drying air velocity increased from 0.5 to $1.0 \mathrm{~m} / \mathrm{s}$. It also increased linearly from $9.92 \times 10^{-10}$ to $1.59 \times 10^{-9} \mathrm{~m}^{2} / \mathrm{s}$ at drying air temperature $40^{\circ} \mathrm{C}$ and it increased linearly from $1.311 \times 10^{-9}$ to $1.52 \times 10^{-9} \mathrm{~m}^{2} / \mathrm{s}$ at drying air temperature $50^{\circ} \mathrm{C}$. These values were within the general range $10^{-6}-10^{-13}$ $\mathrm{m}^{2} / \mathrm{s}$ for drying of several of food materials while the majority (92\%) falls within $10^{-12}$ and $10^{-8} \mathrm{~m}^{2} \mathrm{~s}^{-1}$, (Zogzas et al. 1996).

Since the first phenomenon is more substantial, the resulting effect of increase in air temperature the moisture diffusion increases which results in a drying rate increase. 
By using Eqn. 4, the activation energy can be determined from the slope of Arrhenius plot, $\ln \left(D_{\text {eff }}\right)$ versus $1 /(\mathrm{T}+273.15)$. The $\ln D_{\text {eff }}$ as a function of the reciprocal of absolute temperature was plotted in Fig. 11. The slope of the line is $\left(-E_{a} / R\right)$ and the intercept equals $\ln \left(D_{0}\right)$. The results show that it could be a linear relationship because of Arrhenius-type dependence and for his relation was $\mathrm{R}^{2}=0.963$. The activated energy of Lemon Balm (Melissa officinalis L.) was calculated and found to be 24.6 to $26.62 \mathrm{~kJ} / \mathrm{mol}$. The activation energy value of foods was in the range of values (15-40 kJ/mol) reported by Rizvi (1986) for various food materials such as green bean $(37.716 \mathrm{~kJ} / \mathrm{mol})$, lettuce and cauliflower leaves $(19.82$ $\mathrm{kJ} / \mathrm{mol})$ and mushroom $(23.59 \mathrm{~kJ} / \mathrm{mol})$.

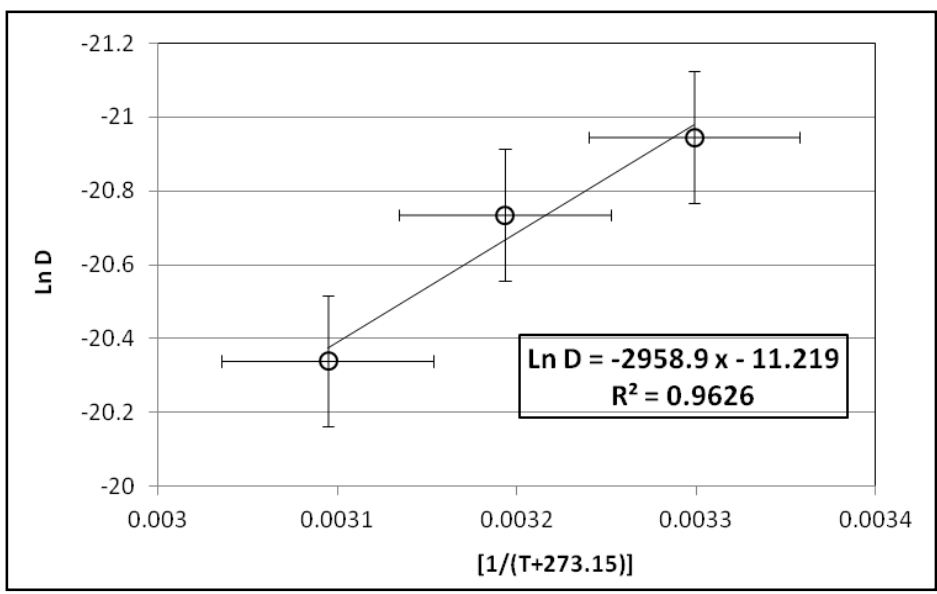

Fig. 11. In $\left(D_{\text {eff }}\right)$ for Melissa versus $1 /(T+273.15)$.

\section{CONCLUSION}

Moisture loss of Lemon Balm (Melissa officinalis L.) increased with an increase of drying air temperature. The overall performance of the herbs dried at $50^{\circ} \mathrm{C}$ was the best, when drying time was considered.

Lemon Balm (Melissa officinalis L.) should be dried at an air velocity equal to or just above $0.75 \mathrm{~m} / \mathrm{s}$. Above this air velocity, moisture loss became independent of air velocity. 
The experimental data were fitted to determine the drying constant " $k$ " for drying lemon balm in thin layer at different drying air conditions as the following equation:

$$
\mathrm{k}=1.342-0.010 \mathrm{~T}-0.025 \mathrm{RH} \quad \mathrm{R}^{2}=0.9054
$$

The analysis revealed that the drying constant " $k$ " showed a highly dependent on both air temperature and relative humidity.

The effective moisture diffusivity of Lemon Balm (Melissa officinalis L.) increased linearly from $9.2214 \times 10^{-10}$ to $1.131 \times 10^{-9} \mathrm{~m}^{2} / \mathrm{s}$ as drying air temperature increased from 30 to $50^{\circ} \mathrm{C}$.

The activated energy of Lemon Balm (Melissa officinalis L.) was calculated $24.62 \mathrm{~kJ} / \mathrm{mol}$. Hence, thin-layer of Lemon Balm (Melissa officinalis L.) may be dried at an air temperature of $50^{\circ} \mathrm{C}$ and air velocity of $0.75 \mathrm{~m} / \mathrm{s}$ and Two-term model may be recommended to describe the single layer drying of Lemon Balm (M. officinalis L.).

\section{RECOMMANDITIONS}

- This unit of laboratory dryer can be used to determine the drying constant " $k$ " for thin layer of lemon balm at the different mathematical models which was developed previously for other agricultural products.

- This unit of laboratory dryer can be used to determine the moisture diffusivity of other plants, fruits, and vegetables.

\section{REFERENCES}

Abdel Ghaffar, E. A., Shokr, A. Z., Rashwan, M. A. and Shaaban, S.

S. (2011). Effect of natural and solar energy drying systems on drying characteristics of Marigold medical plants. Misr J. of Ag. Eng., 28 (3): 719-733. 
Akpinar, E. K. (2006). Mathematical modelling of thin layer drying process under open sun of some aromatic plants. Journal of Food Engineering, 77, 864-870.

Alibas, I. (2007). Energy consumption and color characteristics of nettle leaves during microwave, vacuum and convective drying. Biosystems Engineering, 96(4): 495-502.

Arafa, G. K. (2007). Optimum drying conditions for thin-layer drying of sweet basil. Misr J. of Ag. Eng., 24 (3): 540-556.

Argyropoulos, D., Kudadam, J., and Müller, J. (2009). Color Degradation of Lemon Balm (Melissa officinalis L.) as Affected by the Drying Process. $5^{\text {th }}$ CIGR Section VI International Symposium on Food Processing, Monitoring Technology in Bioprocesses and Food Quality Management. Potsdam, Germany.

Buser, M. D., Stone, G. H., Bruswitz, Moness, N. O. and Whitelock, D. P. (1999). Thin-layer drying of marigold flowers and flower components for petals removal. Transactions of the ASAE. 42(5): 1367-1373.

Crank, J. (1975). The Mathematics of Diffusion; Oxford University Press: Oxford.

Halsey, G. (1985). Physical adsorption on uniform surface. Chemical Physics. 16 (10): 931-936.

Lee, G., and Hsieh, F. (2008). Thin-layer drying kinetics of strawberry fruit leather. Transactions of the ASABE, 51(5): 1699-1705

Matouk, A. M.; Abedel-Latif. S. M.; El-Hadidi, Y. M. and Tharwat, A. (2002). Drying of ear corn. Part II: Thin layer drying equations. The $10^{\text {th }}$ Conf. Misr J. of Ag. Eng., 19 (4): 139-154.

Mosallam, M. A., Zaalouk, A. k. and Werby, R. A. (2011). Thin layer drying of watermelon seeds (Colocynthis Citullus). Misr J. of Ag. Eng., 28 (2): 440-450. 
Rizvi, S. S. H. (1986). Thermodynamic properties of foods in dehydration. In: Rao, M. A. and S. S. H. Rizvi (Ed.), Engineering properties of foods (pp. 190-193). Marcel Dekker Inc., New York.

Shokr, A. Z., Abdel Ghaffar, E. A., Rashwan, M. A. and Shaaban, S. S. (2011). Development of the drying characteristic coefficients of dried Marigold plants by using of an electrical laboratory drying system. Misr J. of Ag. Eng., 28 (1): 181-200.

Soysal, Y. (2004). Microwave drying characteristics of parsley. Biosystems Engineering, 89, 167-173.

Zogzas, N. P., Maroulis, Z. B., and Marinos-Kouris, D. (1996). Moisture Diffusivity Data Compilation in Foodstuffs. Drying Technology, 14: (10), 2225 - 2253.

\section{الملخص العربي}

تقدير الظروف المثلى لتجفيف طبقة رقيقة من أوراق نبات الميلسا

$$
\text { د. باهر محمود أحمد عامر }
$$

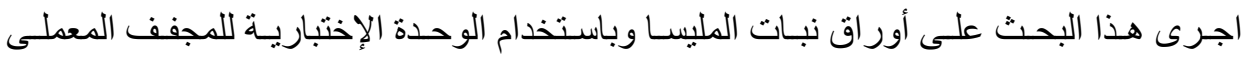
و الموجودة فى معهد الهندسة الزر اعية بمدينة بوتسدام بألمانيا.

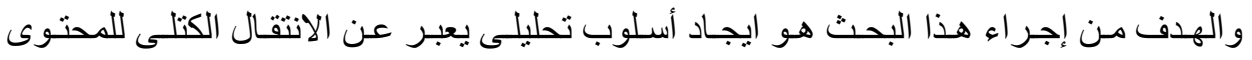

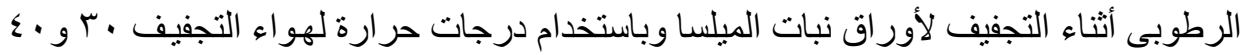

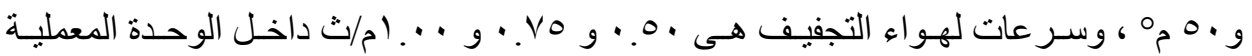
الإختبارية ، وكذلك تقدير ثابت التجفيف فى العلاقة الرياضية المعبرة عن نسبة التجفيف للطبقة

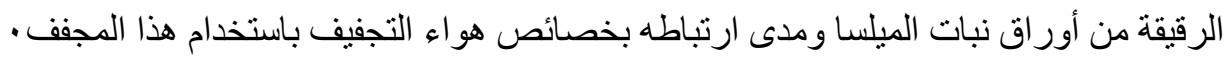

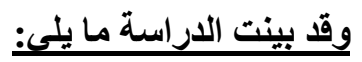

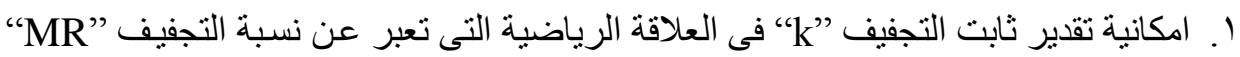

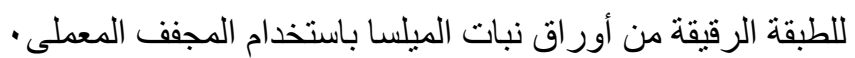

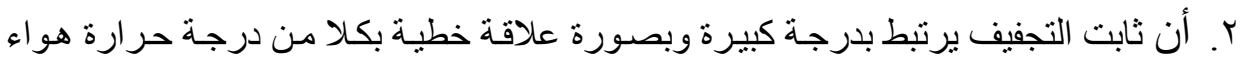

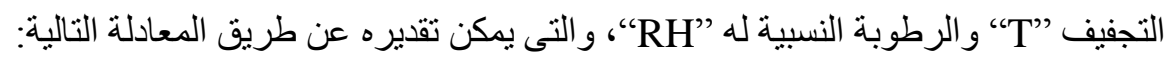
$\mathrm{k}=1.342-0.010 \mathrm{~T}-0.025 \mathrm{RH} \quad \mathrm{R}^{2}=0.9054$ 


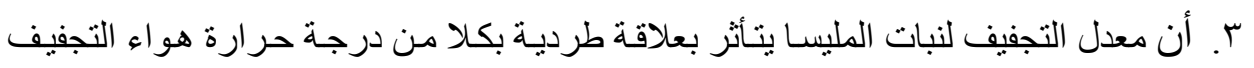
بصورة كبيرة وبصورة أقل يتأثر بسر عة الهو اء المستخدم فى التجفيف.

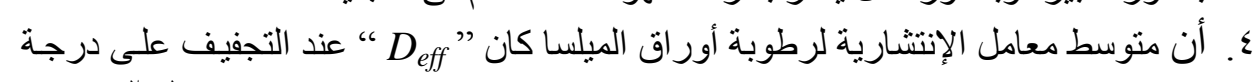

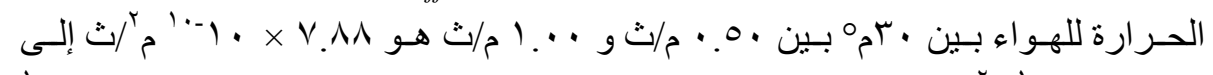

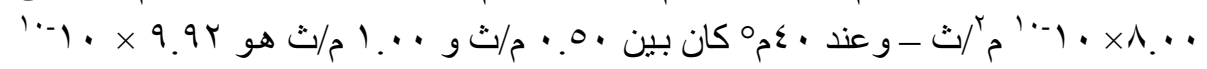

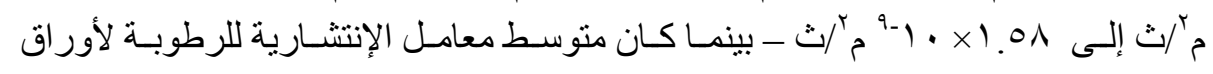

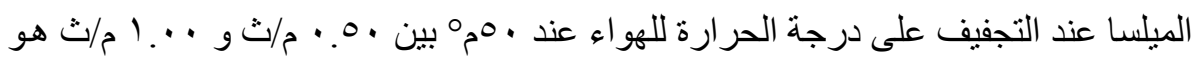

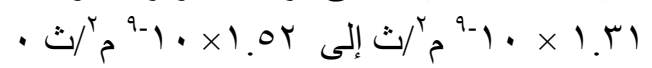

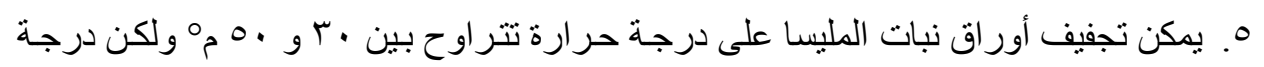

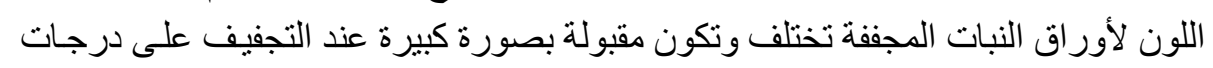

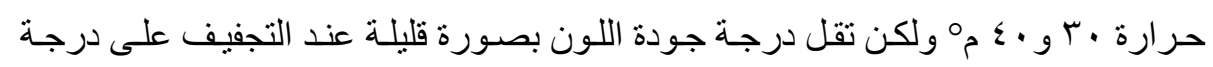
. 0 .

\section{التوصيات}

يمكن استخدام هذا المجفف المعملى وذللك لتقدير ثابت التجفيف لأوراق نبات المليسا . يمكن استخدام هذا المجف المعملى وذلك لتقدير معامل الإنتشارية لرطوبـة منتجات أخرى من النباتات و الفاكهة و الخضر او التخدات . 